\title{
USE OF THE ENZYME GAMMA-GLUTAMYL TRANSFERASE (GGT) AS AN INDIRECT MEASURE OF PASSIVE TRANSFER OF IMMUNITY IN HOLSTEIN CALVES AND ASSOCIATION WITH THE OCCURRENCE OF DIARRHEA AFTER BIRTH
}

\author{
USO DA ENZIMA GAMA-GLUTAMILTRANSFERASE (GGT) COMO MEDIDA \\ INDIRETA DE TRANSFERÊNCIA DE IMUNIDADE PASSIVA EM BEZERRAS DA \\ RAÇA HOLANDESA E ASSOCIAÇÃO COM A OCORRENCIA DE DIARREIA APÓS \\ O NASCIMENTO
}

\author{
Luiz Carlos NEGRI FILHO ${ }^{1}$; Célio Eduardo Sargentin PEREIRA ${ }^{\mathbf{1}}$; \\ Pedro Henrique Newbery CHINEZE ${ }^{2}$; Alexey Leon Gomel BOGADO ${ }^{3}$; \\ Dalton Evert BRONKHORST ${ }^{1}$; Michele LUNARDI ${ }^{4}$; Werner OKANO ${ }^{3}$
}

1. Acadêmico de Medicina Veterinária do Programa de Iniciação Científica PIBIT PIBIC CNPq Universidade Norte do Paraná - UNOPAR, Arapongas, PR, Brasil; 2. Acadêmico de Medicina Veterinária da Universidade Norte do Paraná - UNOPAR, Arapongas, PR, Brasil; 3. Professor doutor do Programa de Pós-graduação em Saúde e Produção de Ruminantes, UNOPAR, Arapongas, Paraná, Brasil; 4. Professora doutora do Programa de Pós-graduação Biociência Animal da Universidade de Cuiabá, Cuiabá, MT, Brasil.

\begin{abstract}
The objective of this study was to determine the gamma-glutamyl transferase (GGT) levels and its relationship with diarrhea and passive transfer of immunity in Holstein calves within 24 hours and 30 days of life from Leopolis municipality, the north Parana region. Colostrum is rich in immunoglobulins and vital for immunity to newborn calves, since bovine placenta does not allow the passage of immunoglobulin to the fetus. Calves undergo various challenges that can lead to disease and death in the first month of life, including diarrhea. Diarrhea has a multifactorial etiology, and the passive immunity transferred through ingestion of colostrum is able to protect the calf against many of these etiologic agents. GGT measurements indirectly infer the amount of immunoglobulin ingested by the calf. Higher serum GGT levels (381.72 IU / L) were found at 24 hours, and a significant reduction was observed at 30 days (66.22 IU / L). When the presence or absence of diarrhea was associated with GGT levels above and below 200 IU / L, no statistical significance $(\mathrm{P}>0.05)$ was observed, since $80 \%$ of animals with diarrhea had serum GGT levels higher than 200 IU / L. Under the conditions of this study, there was no relationship between the GGT concentration and the occurrence of diarrhea, and no mortality was observed despite some animals presented diarrhea.
\end{abstract}

KEYWORDS: Colostrum. Immunoglobulin. Newborn calves. Passive immunity.

\section{INTRODUCTION}

Calves undergo various challenges that can lead to disease and death in the first month of life, including diarrhea, since it affects growth and may even increase age at first calving (BARTELS et al., 2010). Furthermore, spending on medications and calf management can lead to substantial economic loss to the producer (SMITH, 2012). Diarrhea has a multifactorial etiology (CHO et al., 2013), and the passive immunity transferred through ingestion of colostrum is able to protect calves against many of these etiologic agents (GODDEN, 2008).

However, the bovine placenta is epitheliochorial, preventing the passage of immunoglobulins to the fetus (JASTER, 2005), thus the inadequate intake of these antibodies in the first 24 to 48 hours after birth (BRITTI et al., 2005) makes the animals more susceptible to diseases. The non-selective intestinal absorption during the first
24 to 48 hours in calves enables direct absorption of various proteins and macromolecules by enterocytes (WAVER et al., 2000), where various enzymes coming from colostrum are absorbed, including gamma-glutamyl transferase (GGT) (BRITTI et al., 2005). Colostrum has a high concentration of this enzyme, allowing the indirect determination of the immunity level of these animals (ZARILLI et al., 2003).

Thompson and Pauli (1981) found that the GGT levels increased up to 16 times in young animals when compared with adult animals. The serum GGT activity can be about 60 times higher in animals breastfed colostrum than in animals not ingesting colostrum. Parish et al. (1997) found GGT values 400 to 800 times higher in colostrum than in serum from adult cattle, evidencing that GGT may be inferred colostrum Ig transfer, as also reported by Peckan et al. (2013), Güngör, Bastan, Erbil (2004), Maden et al. (2004) and Parsih et al. (1997). 
This study aimed to evaluate the passive transfer of immunity of dairy cattle by GGT measurements at 24 hours and 30 days of life, and correlate with the presence or absence of diarrhea.

\section{MATERIAL AND METHODS}

The study was carried out from December 2009 to February 2010, on a dairy farm located in the municipality of Leópolis, north of Paraná State ( $23^{\circ} 04^{\prime} 48^{\prime \prime} \mathrm{S}, 50^{\circ} 45^{\prime} 04^{\prime \prime} \mathrm{W}, 486 \mathrm{~m}$ altitude).

The herd consisted of Holstein cattle black and white variety, raised in free-stall housing system. Eighteen calves were evaluated after birth, which remained with their mothers for about six hours ingesting colostrum ad libitum. Then, they were kept in individual housing, which was changed weekly. The animals received four liters of colostrum twice a day for 48 hours after birth. After this period, the same management was carried out for the milk supply, in addition to offering specific granulated feed for calves ad libitum. Blood samples were taken at $24 \mathrm{~h}$ and 30 days after birth. Blood was taken from the vena jugularis after local antisepsis with $70 \%$ alcohol and placed in Vacutainer® tubes without anticoagulant. After serum separation, it was transferred to an Eppendorf® tube and kept at $-20{ }^{\circ} \mathrm{C}$ until analysis. The enzyme activity was measured using continuous kinetic method for photometric determination using the GAMMA GT Liquiform Labtest ${ }^{\circledR}$ kit (Labtest Diagnóstica SA, Belo Horizonte, BR), in the Clinical Pathology Laboratory of Pharmacy, at North Paraná University (UNOPAR), Arapongas Campus.

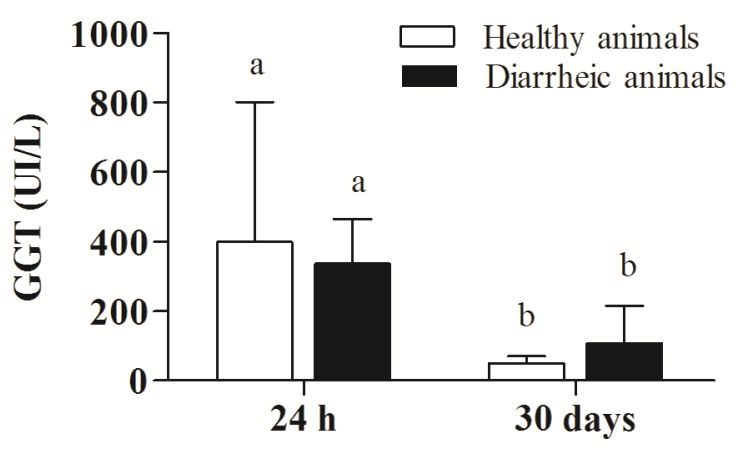

Figure 1. Mean and standard deviation of serum GGT levels in calves with $(n=5)$ and without diarrhea $(n=13)$ after birth (24 hours and 30 days) in the city of Leópolis, north of Paraná State. Different letters on bars indicate difference $(\mathrm{p}<0.05)$ between groups by Kruskal Willis test.

Six animals were below the parameter established for serum GGT levels without the presence of diarrhea in calves within 24 hours of birth, with the lowest concentration of $38.3 \mathrm{IU} / \mathrm{L}$, and one animal with diarrhea (182.30 IU / L) at 14
The animals were monitored throughout the experiment to verify the occurrence of diarrhea, regardless of its etiological origin.

The GraphPad Prism 5 (GraphPad Software Inc., San Diego, CA, USA) was used to construct the graph and statistical analysis, and the groups of healthy and diarrheic animals were compared using Kruskal-Willis test at 5\% significance level (P $<0.05$ ). The relationships between GGT concentrations after birth and the occurrence of diarrhea were analyzed using Epi Info software, version 7.0, by Fischer's exact test at 5\% significance level $(\mathrm{P}<0.05)$.

This study is within the standards of the Ethics Committee for Research on Animals of UNOPAR.

\section{RESULTS AND DISCUSSION}

Feitosa et al. (2001) described that calves with serum GGT levels below 200 IU / L have failure in passive immunity. Taking this parameter into account, in this study, no difference was observed $(\mathrm{P}>0.05)$ in serum GGT levels for both healthy and diarrheal calves (mean and standard deviation of $399.1 \pm 402.3$ and $336.4 \pm 128.3$, respectively), and the same occurred at 30 days $(50.4 \pm 19.1$ and $107.3 \pm 107.4$, respectively) (Figure 1). No animals died during the study period. Garcia et al. (2012) studied GGT in Holstein heifers and found mean values of 167.20 IU and 17.76 IU for 24 hours and 30 days of life, respectively. 
of animals with diarrhea had serum GGT levels higher than $200 \mathrm{IU} / \mathrm{L}$ (Table 1).

Perino, Sutherland, Woollen (1993), and Feitosa (2001) found $87.5 \%$ (7/8) mortality of animals with GGT values lower than $200 \mathrm{IU} / \mathrm{L}$ dosed within 24 hours, being considered failure of passive transfer.

After 30 days, the serum GGT levels in calves were less than $200 \mathrm{IU} / \mathrm{L}$ in $94.4 \%$ (17/18) animals. There was no difference $(\mathrm{P}>0.05)$ between GGT levels and the occurrence of diarrhea, and all healthy animals $(100 \%$ - 13/13) had GGT levels below $200 \mathrm{IU} / \mathrm{L}$. However, it was observed that $80 \%(4 / 5)$ of animals with diarrhea also showed GGT levels below the recommended value, and one animal $(20 \%$ - 1/5) presented diarrhea, even at GGT levels above $200 \mathrm{IU} / \mathrm{L}$ (Table 1).

Table 1. Relationship between GGT levels after birth and occurrence of diarrhea in calves of Leopolis region in north Parana.

\begin{tabular}{cccc}
\hline Variables & $\mathbf{\leq 2 0 0}$ IU/L & $\mathbf{> 2 0 0}$ IU/L & P value \\
\hline GGT 24 h & & & \\
Healthy & $43.2 \%(6 / 13)$ & $53.9 \%(7 / 13)$ & 0.60 \\
Diarrheic & $20.0 \%(1 / 5)$ & $80.0 \%(4 / 5)$ & \\
Total & $38.9 \%(7 / 18)$ & $61.1 \%(11 / 18)$ & \\
GGT 30 days & & & \\
Healthy & $100.0 \%(13 / 13)$ & $0.0 \%(0 / 13)$ & 0.28 \\
Diarrheic & $80.0 \%(4 / 5)$ & $20.0 \%(1 / 5)$ & \\
Total & $94.4 \%(17 / 18)$ & $5.6 \%(1 / 18)$ & \\
\hline
\end{tabular}

GGT: Gamma-Glutamil Transferase; IU/L: International Units per liter.

No relationship between the GGT concentration and the occurrence of diarrhea was observed in this study, since there was no mortality despite some animals presented diarrhea. It is likely that the health management adopted in the property decreased the exposure of calves to challenging situations.

Despite the high $\operatorname{IgG}$ levels are correlated with high GGT concentrations (THOMPSON; PAULI, 1981; PARISH et al., 1997; ROCHA et al., 2009; FEITOSA et al., 2007), there is no consensus on the combination of passive transfer of immunity and protection against morbidity or mortality (BERGE et al., 2009, VIRTALA et al., 1999).

Similarly, Parish et al. (1997) described that the failure in passive immunity occurs when GGT is below $50 \mathrm{IU} / \mathrm{L}$, which confronts with the concentration of $200 \mathrm{IU} / \mathrm{L}$ reported by Feitosa et al. (2001).
Feitosa et al. (2001) reported that as age advances, there is a decrease in GGT levels due to renal filtration or biological degradation, which was also observed in this study, with marked difference between the values at $24 \mathrm{~h}$ and 30 days after birth $(\mathrm{p}<0.01)$.

\section{CONCLUSION}

Under the conditions of this study, there was no relationship between the GGT concentration and the occurrence of diarrhea, and no mortality was observed despite some animals presented diarrhea. More studies are needed with larger numbers of animals to establish a better relationship between passive immunity measured by indirect methods and the protection against diarrhea.

RESUMO: O colostro é rico em imunoglobulinas e vital para a imunidade de bezerros recém-nascidos, uma vez que placenta bovina não permite a passagem de imunoglobulinas para o feto. Os bezerros são submetidos a diversos desafios que podem levar à doença e morte no primeiro mês de vida, dentre as quais a diarreia. A etiologia da diarreia é multifatorial e a imunidade passiva transferida através da ingestão de colostro é capaz de proteger o bezerro contra muitos desses agentes etiológicos. O objetivo deste estudo foi determinar a dosagem de gama-glutamil transferase (GGT) e sua relação com diarreia e a transferência de imunidade passiva em novilhas da raça Holandesa nos tempos de 24 horas e 30 dias de vida, no município de Leópolis, na região norte do Paraná. As mensurações de GGT infere indiretamente a quantidade de imunoglobulinas ingeridas pelo bezerro. Os níveis séricos de GGT demonstraram valores médios maiores 24 horas após o nascimento (381,72 UI / L) e uma redução significativa foi observada aos 30 dias de vida (66,22 UI/L). 
Quando a presença ou ausência de diarreia foi associada com níveis de GGT acima e abaixo de 200UI/L, não foi observado significância estatística ( $>00,05)$, uma vez que $80 \%$ dos animais com diarreia tinham níveis séricos de GGT superior a $200 \mathrm{UI} / \mathrm{L}$. Sob as condições que foi realizado o presente estudo, não houve relação entre a concentração de GGT e a ocorrência de diarréia, e nenhuma mortalidade foi observada apesar de alguns animais apresentarem diarreia.

PALAVRAS-CHAVE: Bezerros recém-nascidos. Colostro. Imunidade passiva. Imunoglobulina.

\section{REFERENCES}

BARTELS, C. J.; HOLZHAUER, M.; JORRITSMA, R.; SWART, W. A.; LAM, T. J. Prevalence, prediction and risk factors of enteropathogens in normal and non-normal faeces of young Dutch dairy calves. Prev. Vet. Med., Amsterdan, v. 93, p. 162-169, 2010.

BERGE, A. C.; BESSER, T. E.; MOORE, D. A.; SISCHO, W. M. Evaluation of the effects of oral colostrum supplementation during the first fourteen days on the health and performance of preweaned calves. J. Dairy Sci., Lancaster, v. 92, p. 286-295, 2009.

BRITTI, D.; MASSIMINI, G.; PELI, A.; LUCIANI, A.; BOARI, A. Evaluation of serum enzyme activities as predictors of passive transfer status in Lambs. J. Am. Vet. Med. Assoc., New York. v. 226, n. 6, p. 951-955, 2005.

CHO. Y. I.; HAN, J. I.; WANG, C.; COOPER, V.; SCHWARTZ, K.; ENGELKEN, T.; YOON, K. J. Casecontrol study of microbiological etiology associated with calf diarrhea. Vet. Microbiol., Amsterdan, v. 166, p. 375-385, 2013.

FEITOSA, F. L. F.; BIRGEL, B. H.; MIRANDOLA, S. M. R.; PERRI, V. H. S. Diagnóstico de falha de transferência de imunidade passiva em bezerros através da determinação de proteína total e de suas frações eletroforéticas, imunoglobulinas g e $\mathrm{m}$ e da atividade da gama glutamil transferase no soro sangüíneo. Cienc. Rural., Santa Maria, v. 31, n. 2, p. 251-255, 2001. http://dx.doi.org/10.1590/S0103-84782001000200010

FEITOSA, F. L. F.; MENDES, L. C. N.; PEIRO, J. R.; CADIOLI, F. A.; YANAKA, R.; BOVINO, F.; FERES, F. C.; PERRI, S. H. V. Influência da faixa etária nos valores de enzimas hepáticas e de uréia e creatinina em bezerros holandeses do nascimento até os 365 dias de vida. Cienc. Vet., Recife, v. 10, n. 2-3, p. 54-61, 2007.

GARCIA, R. A. S.; OKANO, W.; BARCA JUNIOR, F. A.; DA SILVA, L. C.; CUNHA FILHO, L. F. C.; LISBOA, J. A. N.; BALARIN, M. R. S.; HEADLEY, S. A. Evaluation of the transfer of passive immunity by the analysis of immunoglobulin and serum proteins of Holstein calves. Semina Cienc. Agrar., Londrina, v. 33, n. 4, p. 1515-1520, 2012.

GODDEN, S. Colostrum management for dairy calves. Vet. Clin. North Am. Food Anim. Pract., Philadephia. v. 24, p. 19-39, 2008.

GÜNGÖR, Ö., BASTAN, A., ERBIL, M.K., The Usefulness of the $\gamma$-glutamyltransferase activity and total proteinemia in serum for detection of the failure of immune passive transfer in neonatal calves. Rev. Med. Vet., 2004, v. 155, n. 1, p. 27-30.

JASTER, E. H. Evaluation of quality, quantity, and timing of colostrum feeding on immunglobulin G1 absorbtion in Jersey calves. J Dairy Sci., Lancaster, v. 88, p. 296-302, 2005.

MADEN, M.; BIRDANE, F. M.; ALTUNOK, V.; DERE, S. Serum and colostrum/milk alkaline phosphatase activities in the determination of passive transfer status in healthy lambs. Rev. Med. Vet., Toulouse, v. 155, p. 565-569, 2004. 
PARISH, S. M.; TYLER, J. W.; BESSER, T. E.; GAY, C. C.; KRYTENBERG. D. (1997): Prediction of Serum IgG1 concentration in holstein calves using serum gamma glutamyltransferase activity. J. Vet. Intern. Med., Philadelphia, v. 11, p. 344-347, 1997. http://dx.doi.org/10.1111/j.1939-1676.1997.tb00478.x

PEKCAN, M.; FIDANCI, U. R.; YUCEER, B.; OZBEYAZ, C. Estimation of passive immunity in newborn calves with routine clinical chemistry measurements. Ankara Üniv. Vet. Fak. Derg., Ankara, v. 60, p. 85-88, 2013.

PERINO, L. J.; SUTHERLAND, R. L.; WOOLLEN, N. E. Serum gamma-glutamyltransferase activity and protein concentration at birth and after sukling in calves with adequate and inadequate passive transfer immunoglobulin G. Am. J. Vet. Res., Chicago, v. 54, n. 1, p. 56-59, 1993.

ROCHA, T. G.; FRANCIOSI, C.; NOCITI, R. P.; NOGUEIRA, C. A. S.; SAMPAIO, A. A. M.; FAGLIARI, J. J. Transferência de imunidade passiva em bezerros mestiços Canchim-Nelore. In: Cienc. An. Bras, 2009, Goiania. Anais do VIII Congresso Brasileiro de Buiatria, 2009. p. 58-63.

SMITH, D. R. Field Disease Diagnostic Investigation of Neonatal Calf Diarrhea. Vet. Clin. North Am. Food Anim. Pract., Philadephia. v. 28, p. 465-481, 2012.

THOMPSON, J. C.; PAULI, J. V. Colostral transfer of gamma glutamyl transpeptidase in calves. N. Z. Vet. J., Wellington, v. 29, n. 12, p. 223-226, 1981.

VIRTALA, A. M.; GROHN, Y. T.; MECHOR, G. D.; ERB, H. N. The effect of maternally derived immunoglobulin $\mathrm{G}$ on the risk of respiratory disease in heifers during the first 3 months of life. Prev. Vet. Med., Amsterdam. v. 39, p. 25-37, 1999.

WEAVER, D. M.; TYLER, J. W.; VANMETRE, D. C.; HOSTETLER, D. E.; BARRINGTON, G. M. 2000. Passive transfer of colostral immunoglobulins in calves. J. Vet. Intern. Med., Philadelphia. v. 14, p. 569-577, 2000.

ZARILLI, A.; MICERA, E.; LACARPIA, N.; LOMBARDI, P.; PERO, M. E.; PELAGALLI, A.; ANGELO, D.; MATTIA, M.; AVALLONE, L. Evaluation of goat colostrum quality by determining enzyme activity levels. Livest. Prod. Sci., Amsterdam. v. 83, p. 317-320, 2003. 